- ORIGINAL ARTICLE

Volume 10 Issue 12018

DOI: 10.21315/eimj2018.10.1.5

ARTICLE INFO

Submitted: 04-02-2018

Accepted: 21-02-2018

Online: 30-03-2018

\section{Which Personality Traits Have Favourable Impact on Psychological Health During Stressful Condition?}

\author{
Muhamad Saiful Bahri Yusoff \\ Department of Medical Education, School of Medical Sciences, \\ Universiti Sains Malaysia, Kelantan, MALAYSIA
}

To cite this article: Yusoff MSB. Which personality traits have favourable impact on psychological health during stressful condition? Education in Medicine Journal. 2018;10(1):35-42. https://doi. org/10.21315/eimj2018.10.1.5

To link to this article: https://doi.org/10.21315/eimj2018.10.1.5

\title{
ABSTRACT
}

Personality researchers have proposed five dimensions of personality that are extroversion, conscientiousness, agreeableness, neuroticism, and openness. The five-factor model offers a theoretical basis for medical educators to understand the impact of personality traits on medical students' psychological health during stressful medical training. This study attempted to investigate on which personality traits have favour impact on psychological health of medical students during a stressful period - the final examination of first year. A cross-sectional study was conducted on medical students in a public medical school. Personality traits were measured by USM Personality Inventory and psychological health parameters were measured by 21-item Depression Anxiety Stress Scale. Pearson correlation test was performed by SPSS to determine correlation between personality trait and psychological health parameters. A total of 174 medical students participated in this study. Extroversion $\left(\mathrm{r}_{\text {stress }}=-0.44, \mathrm{r}_{\text {anxiety }}=-0.41, \mathrm{r}_{\text {depression }}=-0.56\right)$, conscientiousness $\left(\mathrm{r}_{\text {stress }}=-0.38, \mathrm{r}_{\text {anxiety }}=\right.$ $\left.-0.36, \mathrm{r}_{\text {depression }}=-0.51\right)$, agreeableness $\left(\mathrm{r}_{\text {stress }}=-0.28, \mathrm{r}_{\text {anxiety }}=-0.25, \mathrm{r}_{\text {depression }}=-0.47\right)$ and openness $\left(\mathrm{r}_{\text {stress }}=-0.34, \mathrm{r}_{\text {anxiety }}=-0.31, \mathrm{r}_{\text {depression }}=-0.47\right)$ negatively correlated with stress, anxiety and depression. Neuroticism $\left(\mathrm{r}_{\text {stress }}=0.53, \mathrm{r}_{\text {anxiety }}=0.47, \mathrm{r}_{\text {depression }}=0.60\right)$ positively correlated with stress, anxiety and depression. Extroversion, conscientiousness, agreeableness and openness demonstrated favourable impact and neuroticism demonstrated unfavourable impact on stress, anxiety and depression of the medical students during a stressful period.

Keywords: Personality traits, Psychological health, Medical students

Dr. Muhamad Saiful Bahri Yusoff, Department of Medical Education, School of Medical Sciences, Universiti Sains Malaysia, 16150 Kota Bharu, Kelantan, Malaysia | Email: msaiful_bahri@usm.my

\section{INTRODUCTION}

Personality refers to constant patterns of emotional, mental, social and behaviour characteristics that differentiate one person to other person and the core characteristics that remain constant for life are called as traits (1). Five dimensions of personality are proposed by personality researchers that include extroversion, conscientiousness, agreeableness, neuroticism, and openness $(2-4)$. The five-factor structure has been considered as a scientifically useful structure in the field (5). Extroversion is characterised by enjoying being with people, energetic, talkativeness, excitability, enthusiasm, high amount of emotional 
expressiveness, and assertiveness (6-8). Conscientiousness is featured by high levels of thoughtfulness, good impulse control and goal-directed behaviour, mindful of details, and being organised (6-8). Agreeableness refers to characteristics such as trustworthiness, generosity, helpfulness, kindness, cooperativeness, and sympathy (6-8). Neuroticism is commonly featured by distress, emotional instability, depression, irritability, anxiety, poor coping ability, moodiness, and sadness (6-8). Openness is attributed by broad range of interest, creativity, imaginative, insightful, artistic, and down-to-earth (6-8). Personality researchers believe that personality traits are long-term predispositions for behaviour, in which they tend to be strongly influenced by our genetic makeup, perhaps as high as $80 \%(1)$. They are thus valid predictors of individual behaviour patterns and styles therefore can be good markers for determining types of job that suit individual differently. Even more, the personality traits appear to be applicable across cultures (3). It is worth mentioning that the five-factor model offers a theoretical basis for medical educators to understand the effects of personality traits on important outcomes during medical training (9), especially during the most stressful conditions such as examinations (10-13).

Previous studies have shown that the personality traits predict performance of individual in various non-medical occupation settings in terms of mental health, cognitive ability, job performance, wellbeing, personal qualities and career success (14-25). Likewise, in the medical setting, the personality traits have been associated with several important areas that include approach to work, mental health, career success, learning approach and academic performance $(16,26-$ 35). In fact, there were some evidence supporting association of personality traits with career choices in medicine (36). It is worthy to mention that the personality traits particularly conscientiousness are found to be the best predictors of job performance and trainability $(37,38)$. This study attempted to investigate on which personality traits have favour impact on psychological health of medical students during the most stressful period, which was during the final examination of first year $(10,11)$.

\section{METHODS}

A cross-sectional study was conducted on the first year medical students in a public medical school in Malaysia.

Data collection was done through guided self-administered questionnaires. Verbal and signed consents were obtained from the study subjects. Instructions and information about the study were given to them. They were clearly informed that the results of this study will not have any influence on their medical study. USM Personality Inventory (USMaP-i) and 21-item Depression Anxiety Stress Scale (DASS-21) were distributed to them immediately after the final examination of first year over. It took less than 10 minutes to completely fill in the questionnaires. The questionnaires were returned immediately after they completely filled in.

Demographic profile pertaining to sex, race, entry qualification (Foundation, High School Certificate or Other), and age were obtained from the study subjects via a form.

The USMaP-i measures personality traits of the study subjects. It has five dimensions based on the Big-Five personality model which were Extroversion, Conscientiousness, Agreeableness, Neuroticism, and Openness (7). Its validity and reliability among students was established $(8,39,40)$. The Cronbach's alpha value for each dimension ranged from 0.634 to $0.831(8,39,40)$.

The DASS-21 measures depression, anxiety and stress levels of the study subjects (41-44). Its validity and reliability among student samples was well established (44). The reliability coefficient of depression, anxiety and stress scales range from 0.81 
to 0.97 , and the three subscales showed discriminative ability to differentiate between psychiatric patient and nonpsychiatric patients (44). Based on the DASS manual for student samples (41-43); (a) Stress level is measured by the stress subscale of the DASS-21; (b) Anxiety level is measured by the anxiety subscale of the DASS-21; and (c) Depression level is measured by the depression subscale of the DASS-21. The DASS-21 was used in this study because it requires less time to administer, it is a well-validated and reliable instrument. Furthermore, studies showed it is superior and more consistent compared to the full-scale version (44).

Data were analysed by the Statistical Package for Social Sciences (SPSS) Version 23. The Pearson correlation test was applied to measure correlation between personality trait scores with stress, anxiety, and depression levels. In general, the correlation coefficient lesser than or equal to 0.20 was considered as weak correlation, more than 0.2 but lesser than 0.8 was considered as moderate correlation, and equal to or more than 0.8 was considered as strong correlation (45).

\section{RESULTS}

Table 1 summarised the participant profiles, majority of them were female, non-Malay, and came from foundation stream.

\begin{abstract}
Extroversion, conscientiousness, agreeableness, and openness negatively correlated with stress, anxiety and depression (Table 2). High level of the personality will result in reduction of stress, anxiety and depression level. The results indicated that the personality traits demonstrated favourable impacts on stress, anxiety, and depression.
\end{abstract}

Table 1: Participant profiles $(\mathrm{N}=174)$

\begin{tabular}{lc}
\multicolumn{1}{c}{ Variable } & $\mathbf{n}(\%)$ \\
\hline Sex & $57(32.8)$ \\
Male & $117(67.2)$ \\
Female & \\
Race & $81(46.6)$ \\
$\quad$ Malay & $93(53.4)$ \\
$\quad$ Non-Malay & \\
Entry qualification & $127(73.0)$ \\
Foundation & $31(17.8)$ \\
High School Certificate & $16(9.2)$ \\
Others & $19.27(0.89)$ \\
Age, mean (SD)
\end{tabular}

Table 2: Correlation between personality traits and psychological parameters $(N=174)$

\begin{tabular}{lccc}
\hline \multirow{2}{*}{ Variable } & \multicolumn{3}{c}{ Correlation coefficient $^{*}$} \\
\cline { 2 - 4 } Extroversion & Stress & Anxiety & Depression \\
Conscientiousness & $-0.437^{* *}$ & $-0.408^{* *}$ & $-0.555^{* *}$ \\
Agreeableness & $-0.384^{* *}$ & $-0.357^{* *}$ & $-0.514^{* *}$ \\
Neuroticism & $-0.279^{* *}$ & $-0.251^{* *}$ & $-0.472^{* *}$ \\
Openness & $0.527^{* *}$ & $0.446^{* *}$ & $0.599^{* *}$ \\
\hline
\end{tabular}

*Pearson correlation test was performed-lesser than or equal to 0.20 was considered as weak correlation, more than 0.2 but lesser than 0.8 was considered as moderate correlation, and equal to or more than 0.8 was considered as strong correlation (45)

${ }^{* *} p$-value less than 0.001 
Conversely, neuroticism positively correlated with stress, anxiety and depression (Table 2). High level of the personality will result in increment of stress, anxiety and depression level. The results indicated that the personality trait demonstrated unfavourable impacts on stress, anxiety and depression.

\section{DISCUSSION}

This study found extroversion, conscientiousness, agreeableness, and openness had favourable impact and neuroticism had unfavourable impact on stress, anxiety and depression of the medical students during a stressful period. Each of personality traits was discussed in the subsequent paragraphs.

Extraversion is characterised by positive experiences and feelings, and is therefore seen as a positive affect (37). In a study conducted on Malaysian undergraduates, extraversion negatively predicted their mental health status (14). Likewise, another study reported extroversion of medical students measured prior to medical training negatively correlated with their stress and depression level at the end of first year medical training (9). In addition, recent meta-analyses showed extraversion was strongly associated with most components of wellbeing including happiness, positive affect, negative affect, overall affect, life satisfaction, and quality of life $(15,17)$. These facts aligned with the results of this study.

This study found conscientiousness had a moderate negative correlation with stress, anxiety and depression. A previous study showed that a greater level in conscientiousness would significantly reduce the odds of developing mental disorders (18). In addition, recent meta-analyses found conscientiousness was moderately associated with components of wellbeing including happiness, life satisfaction, positive affects, negative affect, overall affects, and quality of life $(15,17)$. Conversely, a previous study reported conscientiousness of medical students measured prior to medical training did not correlate with their stress, anxiety, and depression level at the end of first year medical training (9). This suggested that different measurement occasions of personality traits might give different correlation findings.

There were limited numbers of studies reported favourable relationships between agreeableness and psychological health. Other than this study, two previous studies reported agreeableness was significantly associated with components of wellbeing which are happiness, life satisfaction, positive affects, negative affect, and quality of life $(15,17)$. In contrast with this study result, a previous study reported agreeableness of medical students measured prior to medical training did not correlate with their stress, anxiety and depression level at the end of first year medical training (9).

This study found high level of openness will result in reduction of stress, anxiety and depression level. This finding is aligned with previous studies that reported openness was significantly related to some components of wellbeing which include happiness, positive affect and quality of life $(15,17)$. Conversely, openness of medical students measured prior to medical training was not correlated with stress, anxiety, and depression (9).

Neuroticism was reported to have the strongest relationship with mental disorders and psychological distress $(9,14,18,46)$ and indeed there is some evidence showing that it may predict a wide range of physical health disorders even when depression is controlled (46). This is might be due to the predisposition to experience negative feelings towards and having poor coping ability for handling stressful transactions $(15,37)$, and thus making them less fit for high level jobs that are more complicated and stressful $(9,21,47)$. In fact, Lahey reported neuroticism was a negative predictor of quality and longevity of life (46). In addition, recent meta-analyses showed neuroticism were strongly and 
negatively correlated with components of wellbeing including happiness, life satisfaction, positive affects and quality of life $(15,17)$. Even more, a previous study reported neuroticism level of medical students measured prior to medical training was the strongest predictor for stress, anxiety and depression level at the end of first year medical training (9). These facts support the finding of this study.

Several implications of this study could be highlighted. First, this study suggests that prospective medical students with favourable personality traits (high level of extraversion, conscientiousness, agreeableness and openness, and low level of neuroticism) should be given more merits to enter medical training. Second, medical students with favourable personality are more resilience to psychological pressure, and thus might prevent them to develop burnout (48). Lastly, inclusion of personality traits as criteria of student admission can be justified as evident by this study.

Despite the favourable results, this study had several limitations. First, study sample was merely from one medical school and only a cohort of medical student. Future study should sample study subjects from multicentre and different cohorts of medical student. Second, this is a cross-sectional study that only assess look at the snapshot pattern of the relationships between personality traits and psychological health. Future study should conduct a longitudinal study to verify the results. Lastly, this study used non-probability sampling method that might compromise the generalisability of the results. Future study should consider probability sampling method such as simple random sampling to improve the generalisability of results. Considering all these limitations, results of this study should be interpreted within its context and any attempts to generalise the results should be done cautiously.

\section{CONCLUSION}

Extroversion, conscientiousness, agreeableness, and openness demonstrated favourable impact and neuroticism demonstrated unfavourable impact on stress, anxiety and depression of the medical students during a stressful period.

\section{REFERENCES}

1. Sherperd P. Personality matter: the whole brain approach, why we learn, think and behave. Malaysia: Brain Works Media; 2007.

2. McRae RR, Costa PT. Validation of the fivefactor model of personality across instruments and observers. Journal of Personality and Social Psychology. 1987;52:81-90. https:// doi.org/10.1037/0022-3514.52.1.81

3. McRae RR, Costa PT. Personality trait structure as a human universal. American Psychologist. 1997;52:509-16. https://doi. org/10.1037/0003-066X.52.5.509

4. Goldberg LR. Language and individual differences: the search for universals in personality lexicons. In: Wheeler L, editor. Review of personality and social psychology. Beverly Hills, CA: Sage; 1981.

5. Goldberg LR. What are the best ways to describe an individual's personality? Dialogue. 2008;23(9):35-9.

6. Goldberg LR, Johnson JA, Eber HW, Hogan $\mathrm{R}$, Ashton MC, Cloninger CR, et al. The international personality item pool and the future of public-domain personality measures. Journal of Research in Personality. 2006;40:84-96. https://doi.org/10.1016/j.jrp. 2005.08.007

7. Goldberg LR. A broad-bandwidth, public domain, personality inventory measuring the lower-level facets of several five-factor models. In: Mervielde I, Deary I, De Fruyt F, Osterdorf F, editors. Personality psychology in Europe. Tilburg, Netherland: Tilburg University Press; 1999. p. 7-28. 
8. Yusoff MSB, Rahim AFA, Esa AR. The USM personality inventory (USMaP-i) manual. Malaysia: KKMED Publications; 2010. Available from: http:/www.medic.usm. my/dme/images/stories/staff/KKMED/2010/ manual\%20usmap-i.pdf.

9. Yusoff MSB, Mat Pa MN, Mey SC, Aziz RA, Rahim AFA. A longitudinal study of relationships between previous academic achievement, emotional intelligence and personality traits with psychological health of medical students during stressful periods. Education for Health. 2013;26(1):39. https://doi.org/10.4103/1357-6283.112800

10. Yusoff MSB. Impact of summative assessment on first year medical students' mental health. International Medical Journal. 2011;18(3):172-5.

11. Yusoff MSB, Abdul Rahim AF, Baba AA, Ismail SB, Mat Pa MN, Esa AR. The impact of medical education on psychological health of students: a cohort study. Psychology, Health \& Medicine. 2013;18(4):420-30. https://doi.org/10.1080/13548506.2012.740 162

12. Yusoff MSB, Abdul Rahim AF, Baba AA, Ismail SB, Mat Pa MN, Esa AR. Prevalence and associated factors of stress, anxiety and depression among prospective medical students. Asian Journal of Psychiatry. 2013;6(1):128-33. https://doi.org/10.1016/j. ajp.2012.09.012

13. Yusoff MSB, Rahim AFA, Yaacob MJ. Prevalence and sources of stress among Universiti Sains Malaysia Medical Students. Malaysian Journal of Medical Sciences. 2010;17(1):30-7.

14. Nordin NM, Talib MA, Yaacob SN. Personality, loneliness and mental health among undergraduates at Malaysian Universities. European Journal of Scientific Research. 2009;36(2):285-98.
15. Oishi S, Schimmack U. Residential mobility, wellbeing, and mortality. Journal of Personality and Social Psychology. 2010;98(6):980-94. https://doi.org/10.1037/ a0019389

16. Popropat AE. A meta-analysis of the fivefactor model of personality and academic performance. Psychological Bulletin. 2009;135(2):322-38. https://doi.org/10.1037/ a0014996

17. Steele PD, Schmidt J, Shultz J. Refining the relationship between personality and subjective well-being. Psychological Bulletin. 2008;134:138-61. https://doi. org/10.1037/0033-2909.134.1.138

18. Goodwin RD, Friedman HS. Health status and the five-factor personality traits in a nationally representative sample. Journal of Health Psychology. 2006;11(5):643-54. https://doi.org/10.1177/1359105306066610

19. Ferguson E, James D, Madeley L. Factors associated with success in medical school: systematic review of literature. British Medical Journal. 2002;324:952-7. https:// doi.org/10.1136/bmj.324.7343.952

20. Judge TA, Bono Je, Ilies R, Gerhardt MW. Personality and leadershp: a qualitative and quantitative review. Journal of Applied Psychology. 2002;87(4):765-80. https://doi. org/10.1037/0021-9010.87.4.765

21. Seibert SE, Kraimer MA. The five-factor model of personality and career success. Journal of Vocational Behavior. 2001;58:121. https://doi.org/10.1006/jvbe.2000.1757

22. Furnham A, Cheng H. Personality as predictor of mental health and happiness in the East and West. Personality and Individual Difference. 1999;27:395-403. https://oi. org/10.1016/S0191-8869(98)00250-5

23. Tokar DM, Fischer AR, Subich LM. Personality and vocational behavior: a selective review of the literature, 1993-1997. Journal of Vocational Behavior. 1998;53:11553. https://doi.org/10.1006/jvbe.1998.1660 
24. Tett RP, Jackson DN, Rothstein $M$. Personality measures as predictors of job performance: a meta-analytic review. Personnel Psychology. 1991;44:703-42. https://doi.org/10.1111/j.1744-6570.1991. tb00696.x

25. Barrick MR, Mount MK. The big five personality dimensions and job performance: a meta-analysis. Personnel Psychology. 1991;44:1-26. https://doi. org/10.1111/j.1744-6570.1991.tb00688.x

26. McManus IC, Keeling A, Paice E. Stress, burnout and doctors' attitudes to work are determined by personality and learning style: a twelve year longitudinal study of UK medical undergraduates. BMC Medicine. 2004;2(9). https://doi.org/10.1186/17417015-2-29

27. De Raad B, Schouwenburg HC. Personality in learning and education: a review. European Journal of Personality. 1996;10:303-36. https://doi.org/10.1002/ (SICI) 1099-0984(199612)10:5<303::AIDPER262>3.0.CO;2-2

28. Bidjerano T, Dai DY. The relationship between the big-five model of personality and self-regulated learning strategies. Learning and Individual Differences. 2007;17(1):69-81. https://doi.org/10.1016/j. lindif.2007.02.001

29. Barrick MR, Mount MK, Strauss JP. Conscientiousness and performance of sales representatives: test for the mediating effect of goal setting. Journal of Applied Psychology. 1993;78:715-22. https://doi. org/10.1037/0021-9010.78.5.715

30. Steele PD. The nature of procrastination: a meta-analytic and theoretical review of quintessential self-regulatory failure. Psychological Bulletin. 2007;133(1):65-94. https://doi.org/10.1037/0033-2909.133.1.65

31. Vermetten YJ, Lodewijks HG, Vermunt JD. The role of personality traits and goal orientations in strategy use. Contemporary Educational Psychology. 2001;26:149-70. https://doi.org/10.1006/ceps.1999.1042
32. Trapmann S, Hell B, Hirn JOW, Schuler H. Meta-analysis of the relationship between the big five and academic success in university. Journal of Psychology. 2007;215(2):132-51. https://doi.org/10.10 27/0044-3409.215.2.132

33. Tempelaar DT, Gijselaers WH, van der Loeff SS, Nijhuis JFH. A structural equation model analyzing the relationship of student achievement motivations and personality factors in a range of academic subjectmatter areas. Contemporary Educational Psychology. 2007;32(1):105-31. https://doi. org/10.1016/j.cedpsych.2006.10.004

34. Lounsbury JW, Steele RP, Loveland JM, Ginson LW. An investigation of personality traits in relation to adolescent school absenteeism. Journal of Youth and Adolescence. 2004;33(5):457-66. https:// doi.org/10.1023/B:JOYO.0000037637. 20329.97

35. Judge TA, Martocchio JJ, Thoresen CJ. Five-factor model of personality and employee absence. Journal of Applied Psychology. 1997;82(5):745-55. https://doi. org/10.1037/0021-9010.82.5.745

36. McManus IC, Lefored F, Furnham A, Shandi S, Pincus T. Career preference and personality differences in medical school applicants. Psychological, Health and Medicine. 1996;1:235-48. https://doi. org/10.1080/13548509608402221

37. Rothman S, Coetzer EP. The bigfive personality dimensions and job performance. Journal of Industrial Psychology. 2003;29(1):68-74. https://doi. org/10.4102/sajip.v29i1.88

38. Schmidt FL, Hunter JE. The validity and utility of selection methods in personnel psychology: practical and theoretical implication of 85 years of research findings. Pscyhological Bulletin. 1998;124:262-74. https://doi.org/10.1037/0033-2909.124. 2.262 
39. Yusoff MSB, Liew YY, Ling HW, Tan CS, Loke HM, Lim XB, et al. A study on stress, stressors and coping strategies among Malaysian medical students. International Journal of Students' Research. 2011;1(2):45-50. https://doi.org/10.5549/ IJSR.1.2.45-50

40. Yusoff MSB, Rahim AFA, Aziz RA, Mat $\mathrm{Pa} \mathrm{MN}$, See CM, Ja'afar $\mathrm{R}$, et al. The validity and reliability of the USM personality inventory (USMaP-i): its use to identify personality of future medical students. International Medical Journal. 2011;18(4):283-7.

41. Crawford JR, Henry JD. The Depression Anxiety Stress Scales (DASS): Normative data and latent structure in a large non-clinical sample. British Journal of Psychological Society. 2003;42:111-31. https://doi.org/10.1348/014466503321903 544

42. Henry JD, Crawford JR. The short-form version of the Depression Anxiety Stress Scales (DASS-21): construct validity and normative data in a large nonclinical sample. British Journal of Clinical Psychology. 2005;44:227-39. https://doi. org/10.1348/014466505X29657
43. Lovibond SH, Lovibond PF. Manual for the Depression Anxiety Stress Scales. 2nd ed. Sydney: Pscyhology Foundation; 1995.

44. McDowell I. Measuring health: a guide to rating scales and questionnaires. 3rd ed. New York: Oxford University Press; 2006. https://doi.org/10.1093/acprof:oso/978019 5165678.001 .0001

45. Zou KH, Tuncall K, Silverman SG. Correlation and simple linear regression. Radiology. 2003;227(3):617-22. https://doi. org/10.1148/radiol.2273011499

46. Lahey B. Public health significance of neuroticism. Am Psychol. 2009;64(4):24156. https://doi.org/10.1037/a0015309

47. Spector PE, Jex SM, Chen PY. Relations of incumbent affect-related personality traits with incumbent and objective measures of characteristics of jobs. Journal of Organizational Behavior. 1995;16:59-65. https://doi.org/10.1002/job.4030160108

48. Dunn LB, Iglewicz A, Moutier C. A conceptual model of medical student well-being: promoting resilience and preventing burnout. Academic Psychiatry. 2008;32(1):44-53. https://doi.org/10.1176/ appi.ap.32.1.44 